https://dx.doi.org/10.4314/iijikm.v10i1.4

Information Impact:

Journal of Information and Knowledge Management

Vol. 10 (1), June, 2019

ISSN: 2141-4297 (Print) ISSN: 2360-994X (Online)

\title{
Library Staff Utilization of Information and Communication Technology (ICT) for Service Delivery in Special Libraries in North Central Nigeria \\ ${ }^{1}$ Rose Lade Mommoh ${ }^{2}$ Vivien Emmanuel \\ ${ }^{1}$ University of Abuja, Nigeria ${ }^{2}$ Rivers State University Port Harcourt Nigeria
}

\begin{abstract}
The study investigated ICT utilization for service delivery in special libraries in North Central, Nigeria. The study was guided by three objectives and relevant literature related to the study was reviewed. Survey research design was used for the study. The population comprised of one hundred and twenty-six (126) professional and para professional library staff in fifteen (15) research libraries in North Central Nigeria. But the sampled population for the study comprised of eighty three (83) library staff from eight (8) research libraries in the North Central Nigeria. Questionnaire was used for collection of data. Out of eighty three (83) copies of questionnaires administered, seventy six (76) copies were duly completed and the data collected was analyzed using descriptive statistics of frequency counts, percentages and mean score. The study revealed ICT facilities were available for minimal use for service delivery. Major problems hindering utilizations of ICT for service delivery in research libraries of the North Central Nigeria were those of ICT policy and in adequate funds. The study proffered recommendations.
\end{abstract}

Keywords: Special libraries, service delivery, North Central, ICT, Utilizatiion

\section{Introduction}

Information and Communication

Technologies (ICTs) have profoundly

revolutionized the world of libraries, librarianship and information profession as in other walks of life in the last two or three decades. The capabilities of ICTs applications in libraries are great. Islam and
Islam (2007) gave a concise classification of ICT's by usage in libraries as follows: ICT based resources, including computers connected to internet, CD-ROM, audio cassettes, video- cassettes, photocopiers, printers, software used by libraries. ICT based activities includes data processing, circulation, cataloguing, bibliography, serials control, in-house database; and ICT- 
Mommoh, R. S, Emmanuel, V.: Library Staff Utilization of Information and Communication Technology ICT for Service Delivery in Special Libraries in North Central, Nigeria

based library services including CD-ROM searching, online information service, news clipping, scanning service, online reservation services. The benefits of ICT in libraries are numerous. They include; better service delivery to library users, more efficient utilization of library resources, provision of services to both local and global community, as well as more effective way of fulfilling the colossal information needs emerging in the information age (Maxwell, 2011) further stated that the use of ICT in the libraries has tremendously changed the management of resources or housekeeping operations as well as the way services are delivered. The ICT application tools are integrated library systems that are largely used in housekeeping operations, like acquisition, cataloguing, circulation control, serials control. Internet has been used extensively as a resource as well as a tool to deliver library and information needs of the user

The essence of ICT utilization for service delivery in libraries is to improve the quality of services rendered by staff to the library users in order to improve research. ICT in libraries enhance the conduct of research since library staff and users conduct research. Okezie (2009) stated that research is such that, irrespective of one's sophistication and the nature of the investigation, it is not possible to conduct research today without relying on one form of ICT or the other.

ICT in libraries enhance a lot of library services and operations which are better information delivery and access to library services, improved and ensure effective services and increased transparency between the library staff and users which will help in sustaining growth and development (Akintunde 2004). The use of ICT in libraries facilitates cross collaboration and coordination among library management and library staff and ensures easier, faster and appropriate decision making process and planning. This will reduce waste, save time and encourage simple, morale, accountable, responsive and transparent conduct in the delivery of library services (Oketunji, 2002).

Akintunde (2004) stressed that ICT has become an indispensable tool to librarians in the provision of timely information to users and in fact, to the progress of librarianship as a profession. Research has revealed how ICT utilization is fast improving service delivery in special libraries worldwide. With regards to library services, ICT facilities are increasingly becoming veritable tools in enhancing effective services delivery in the 
Mommoh, R. S, Emmanuel, V.: Library Staff Utilization of Information and Communication Technology ICT for Service Delivery in Special Libraries in North Central, Nigeria

modern libraries and information centers (Mohammed 2000). The capability of internet for instance, has improved the access to worldwide information resources. The internet is a tremendous potential for improving service delivery. Not to talk of the capability of the e-mail this has improved communication between the publishers, library users and colleagues, the capability of computer for information storage and retrieval in the library.

Another benefit of ICT in libraries relates to resources sharing. The capability of ICT facilities such as the online public Access catalogue (OPAC) enhance access to the resources of other libraries in any part of the world and CD- ROM databases provides access to resources in related subject areas which help libraries to deliver better services. Akintunde (2004) also stated that libraries use ICT in several ways, which include library management and administration; processing of library materials; developing on-line resources; accessing on-line resources; developing offline resources; accessing offline-resources; provision of regular library services to users; inter-library cooperation and lending and videoconferencing. Special libraries are set up to provide information service in support of research. According to Aina (2004) librarians in special libraries are involved in researching and finding answers for the client rather than client seeking for information with the assistance of the library. How well the special libraries are able to realize this objective in digital age depends on the type of functional ICT facilities that are available and used. It was observed in the course of this study that libraries before now have tried to get the latest information and have attempted to improve their service delivery but all efforts have not yielded the required results because of none availability of information and communication technology at the time. With the advent of ICT and other telecommunication facilities libraries are expected to improve their service delivery by using them. Therefore this study investigates the extent of ICT utilization for service delivery in special libraries in North Central Zone of Nigeria. 
Mommoh, R. S, Emmanuel, V.: Library Staff Utilization of Information and Communication Technology ICT for Service Delivery in Special Libraries in North Central, Nigeria

\section{Objectives of the study}

The specific objectives of the study were to:

1. Determine the ICT facilities available for service delivery in special libraries in North Central Zone Nigeria.

\section{Literature review}

Different types of ICT facilities are available and use in all types of libraries, for the purposes of capturing, processing, storage, retrieval and dissemination of information.

The diversity of ICT available in libraries was captured by Achebe (2005) who identified radio, television, cellular phone, satellite systems, computer keyboards, central processor, modern, telephone line, software and networks such as Local Area Networks (LAN) and Wide Area Network (WAN) as its constituents. Daniel, Oketunji, Okojie and Abdulsalam (2003) have observed that the information technologies found in libraries today is a combination of computers, storage media and
2. Investigate the extent of ICT utilization for service delivery in special libraries in North Central Zone Nigeria.

3. Find out the problems associated with the use of ICT for service delivery in special libraries in North Central Zone Nigeria.

telecommunications. In other words computers provide the processing, storage and retrieval capabilities of information in the library while telecommunication provides the capabilities for the transfer and of communication of data (information) from one workstation to another in the library. In the word of Cholin (2001) "ICT encompasses a range of modern technologies and their applications, including all aspects of the use of computers, micro-electronic devices, satellite and communication technology". Oketunji (2001) stated that ICT available for library use include: personal computers, $\mathrm{CD}$ ROM, telefascimile (fax) network; 
Mommoh, R. S, Emmanuel, V.: Library Staff Utilization of Information and Communication Technology ICT for Service Delivery in Special Libraries in North Central, Nigeria

electronic copying (scanning); and internet.

Daniel and Mathew (2000) described the new development as tools for information delivery in the new millennium. Aina (2004) viewed information communication technology (ICT) used in libraries for handling, acquiring, processing, storing and disseminating information to include computers, on-line searching, CD-ROMs and internet. Ukwungwu (2004) in like manner describe ICT in libraries as internet, world, worldwide web (www), e-mail, and telephone.

Faboyinde (2006) reported of computers, Local Area Network, software, and internet services available in some special libraries in Lagos and Ibadan. Some of the special libraries includes: International Institute of Tropical Agriculture (IITA), Ibadan; Nigerian Institute of economic and Social Research (NISER) Ibadan, The Development Centre Ibadan, National Centre for Economic Management and
Administration (NCEMA) Bodija, Ibadan. Mommoh (2006) surveyed twenty three (23) special libraries in Abuja and reported that computers and internet services were available in some of the libraries surveyed. Furthermore, Igben and Akobo (2007) reported availability of ICT such as computers, Local Area Network, software and internet access in some special libraries in Rivers State.

Islam amd Islam (2007) conducted a research study and presented how ICT utilization has improved service delivery to library users in Bangladesh. That the international Centre for Diarrhea Diseases research in Bangladesh (ICCDRB, library) is the pioneer in computerization of information system in Bangladesh. It initiated the programme in 1985 . At present information system unit (LISU) of ICCDRB has 13 computers and among them 12 computers are connected with internet. The LISU provides internet facilities free of 
Mommoh, R. S, Emmanuel, V.: Library Staff Utilization of Information and Communication Technology ICT for Service Delivery in Special Libraries in North Central, Nigeria

charge to library users. The library is connected to databases such as PO PLINE and MEDLINE.

Islam and Islam (2007) further mentioned universities libraries in Bangladesh where ICT are being utilized and services delivery are being improved. Such libraries includes North-South university library (NSU,L); The Independent University, Bangladesh library (IUB Library) East-West University library (EWU, Library) Dhake University library (DUL), Bangladesh University of Engineering and Technology (BUET) Library ; Jahangir agar University library, Bangladesh National Scientific and Technical Documentation Centre (BANSDOC); community Development library (CDL). In these libraries there are computers connected to internet, CD ROM, Audio cassettes, photocopiers printers, software such as GLAS, CDS/ISIS, (Alice for windows). These libraries use ICT in activities such as data processing, bibliography, Serials central and creation of in-house database. The ICTs are used to provide CD-ROM searching, online searching, online networking, and online information services.

In another study by Mairaj and EL-hadi (2012), conducted a research on the availability and use of ICT resources in medical libraries in Pakistan. They reported that ICT resources used in these medical libraries include computers, scanners, DVD barcode reader, fax machine, multi-media projectors, software and databases, internet access, and library website. Digital subscriber's lines are mostly used in this library. Some empirical studies on the use of ICT for library services in special libraries in the North Central Zone of Nigeria have been conducted. Mommoh, (2006) studied application of computer to special library services in the federal capital territory. Twenty- three special libraries were surveyed. Questionnaire was designed to 
Mommoh, R. S, Emmanuel, V.: Library Staff Utilization of Information and Communication Technology ICT for Service Delivery in Special Libraries in North Central, Nigeria

acquire the data for the study. Frequency

count and simple percentage were used to

analyze the data collected. The finding

revealed that out of twenty three (100\%)

special libraries only nine $(39 \%)$ had used

computer for some library services. The

major problem was inadequate fund to

procure computers, maintenance and staff

training.

Several problems are faced with the utilization of ICT in special libraries.

Oketunji (2003) stated that inadequate fund

to handle hardware, software installation and

maintenance of these facilities is a problem.

Some special and research libraries are

poorly funded by their parent organizations

and this has resulted in failure of these tools.

According to Maxwell (2011) lack of

suitable infrastructure for the operation of

ICT in special and research libraries in

Nigeria is an identified problem. It is on

\section{Methodology}

Survey research design was used for this study. The population comprised of one record that the new technologies need adequate equipment to function efficiently and effectively. And part of this is infrastructure is built on uninterrupted power supply. This element is an issue in the operation of ICT in the developing world. Maxwell further identified unskilled man power, lack of zeal, and commitment in the implementation of ICT running the in-house chores in the special libraries on the part of government and management of these Institutes and Ministries. Fanimehin (2008) identified librarian perception, vested interest of the head of department where the library is, poor funding, and lukewarm attitudes of umbrella organizations and lack of clear-cut policy on ICT usage in libraries as some of the problems faced by special libraries in the utilization of ICT for service delivery.

Hundred and twenty-six (126) professional and para professional library staff in fifteen 
Mommoh, R. S, Emmanuel, V.: Library Staff Utilization of Information and Communication Technology ICT for Service Delivery in Special Libraries in North Central, Nigeria

(15) research libraries in North Central Nigeria, but purposive sampling technique was used to select eight (8) special libraries that constitute the sample for the study with a population of eight three (83) library staff. The eight special libraries sampled include; Institute for Peace and Conflict Resolution Library, Abuja (7); National Mathematical Centre Library, Abuja (6); Raw Materials Research and Development Council Library, Abuja (9); Fisheries Research Institute Library, New Bussa (6); National Institute for Policy and Strategic Studies Library,
Jos(22); National Veterinary Research Institute Library, Jos(16); Agriculture and Rural Management Training Institute Library, Ilorin(5) and Nigerian Store Product Research Institute Library, Ilorin (12).

Questionnaires used in data collection were retrieved from professional and non professional library staff. The data relating to the research questions were analyzed using descriptive statistics.

\section{Presentation of Results}

A total of eighty-three (83) copies of questionnaires were administered and seventy six (76) respondents duly completed the questionnaires.
Research Question 1: what is the extent of information communication technologies available for service delivery in special libraries in North Central Nigeria?

Table.1: Library staff response on available of Information Communication Technologies for service delivery in special Libraries in North Central Zone of Nigeria.

$\begin{array}{lcccc}\text { ICT facilities } & \text { Available } & \text { Not } & \text { Total } & \text { Decision } \\ \text { Computer } & 75(98.7 \%) & 1(1.3 \%) & 76 & \text { Available } \\ \text { Internet } & 53(69.9 \%) & 23(30.3 \%) & 76 & \text { Available } \\ \text { CD-ROMs } & 43(56.6 \%) & 27(35.5 \%) & 76 & \text { Available } \\ \text { Printers } & 62(81.6 \%) & 14(18.4 \%) & 76 & \text { Available } \\ \text { Digital Cameras } & 14(18.4 \%) & 62(81.4 \%) & 76 & \text { Available } \\ \text { Video cassette } & 35(46.0 \%) & 41(53.9 \%) & 76 & \text { Available } \\ \text { Photocopier } & 58(76.3 \%) & 18(23.7 \%) & 76 & \text { Available }\end{array}$


Mommoh, R. S, Emmanuel, V.: Library Staff Utilization of Information and Communication Technology ICT for Service Delivery in Special Libraries in North Central, Nigeria

\begin{tabular}{|c|c|c|c|c|}
\hline Scanner & $49(64.5 \%)$ & $27(35.5 \%)$ & 76 & Available \\
\hline Email & $51(67.1 \%)$ & $25(32.9 \%)$ & 76 & Available \\
\hline Electronic Data Base & $47(61.8 \%)$ & $29(38.2 \%)$ & 76 & Available \\
\hline Flash Drives & $22(28.9 \%)$ & $54(71.1 \%)$ & 76 & Available \\
\hline Projector Screen & $44(57.9 \%)$ & $32(42.1 \%)$ & 76 & Available \\
\hline Server & $52(68.4 \%)$ & $24(31.6 \%)$ & 76 & Available \\
\hline Video players/recorders & $32(42.1 \%)$ & $41(53.9 \%)$ & 76 & Available \\
\hline Television & $26(34.2 \%)$ & $42(55.3 \%)$ & 76 & Available \\
\hline Telephone (intercom) & $32(42.1 \%)$ & $44(57.9 \%)$ & 76 & Available \\
\hline Modem & $24(31.6 \%)$ & $52(68.4 \%)$ & 76 & Available \\
\hline Software & $49(64.5 \%)$ & $27(35.5 \%)$ & 76 & Available \\
\hline \multicolumn{5}{|l|}{ Application } \\
\hline OPAC & $42(55.3 \%)$ & $34(44.7 \%)$ & 76 & Available \\
\hline Radio & $18(23.7 \%)$ & $58(76.3 \%)$ & 76 & Available \\
\hline Total & 828 & 692 & 1520 & \\
\hline
\end{tabular}

The result in table 1 shows the number of be above average. Other ICT such as Digital ICT available in special libraries of the the North Central Zone of Nigeria. Computers 75 (98.7\%), Internet $53(69.7 \%)$ CDROM $43(56.6 \%)$, Printers $62 \quad(81.6 \%)$, Photocopiers 58 (76.3\%), Scanner 49 (64.5\%), Email 51 (67.1\%), Electronic Database 47 (61.8\%), Projector Screen 44 (57.9\%), Server 52 (68.4\%), Library Staff Application (64.5\%) and OPAC (55.3\%) were accessed by library staff to be available. The available ICT can be said to camera 14 (18.4\%), Flash drive 22 (28.9\%), Video players/recorders 32 (42.1\%), Television 26 (34.2\%), Telephone (intercom) 32 (42.1\%), Modem 24 (31.6\%) and radio $18(23.7 \%)$ were equally accessed by library staff be available but low. The deduction from this analysis was that ICT available for service delivery in special libraries in North Central Nigeria could translate into more and better use for service delivery. 
Mommoh, R. S, Emmanuel, V.: Library Staff Utilization of Information and Communication Technology ICT for Service Delivery in Special Libraries in North Central, Nigeria

Research Question 2: What is the extent of library staff utilizsation of ICT for service delivery in special libraries in North Central Zone of Nigeria.

Table.2: Responses of library staff on the extent of ICT utilization for service delivery in the special libraries, of North Central Nigeria.

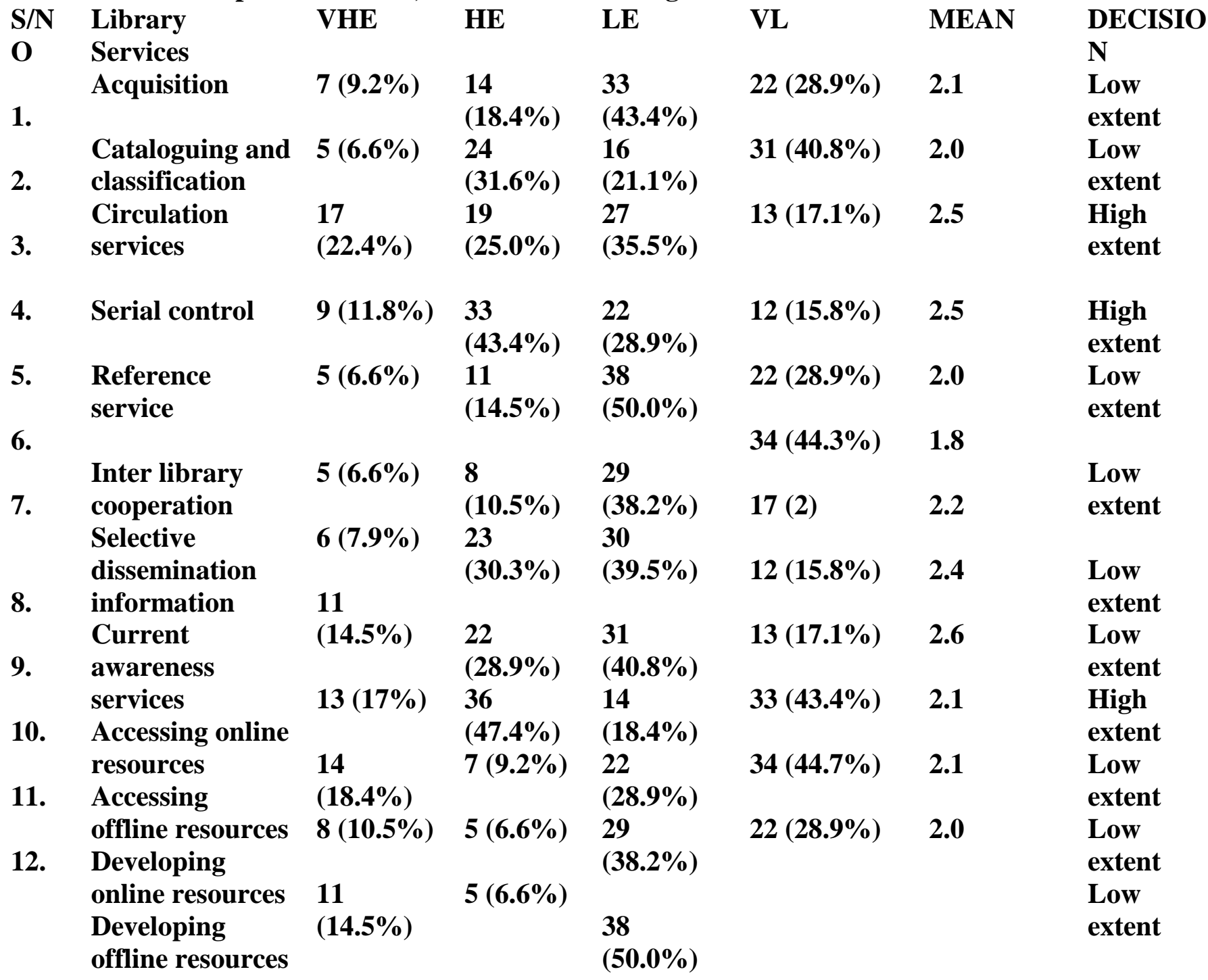

The analysis on ICT utilization for service delivery in special libraries of North Central Zone Nigeria shows that services such as acquisition 2.1, cataloging and classification 2.0, inter library loan 1.8, selective dissemination of information 2.2, current awareness 2.4, accessing offline resources 2.1, developing online resources 2.1 and developing offline resources 2.0 were all accessed by library staffs to be low except for circulation 2.5, reference 2.5 and accessing online resources 2.6 that were 
Mommoh, R. S, Emmanuel, V.: Library Staff Utilization of Information and Communication Technology ICT for Service Delivery in Special Libraries in North Central, Nigeria

accessed by the library staff to be high. The utilization of ICT for the majority of the service delivery in the special libraries was low and the few services that were accessed to be high were just a little above average. The library staff utilization of ICT for service delivery in the special libraries of the
North Central Nigeria could not be said to be of optimum extent as indicated in table 2 . On the basis of the analysis it could be concluded that ICT was minimally utilized in the service delivery of the special libraries by the staff.

Research Question 3: What is the extent of problems associated with the use of ICT for service delivery in special libraries in the North Central Zone of Nigeria?

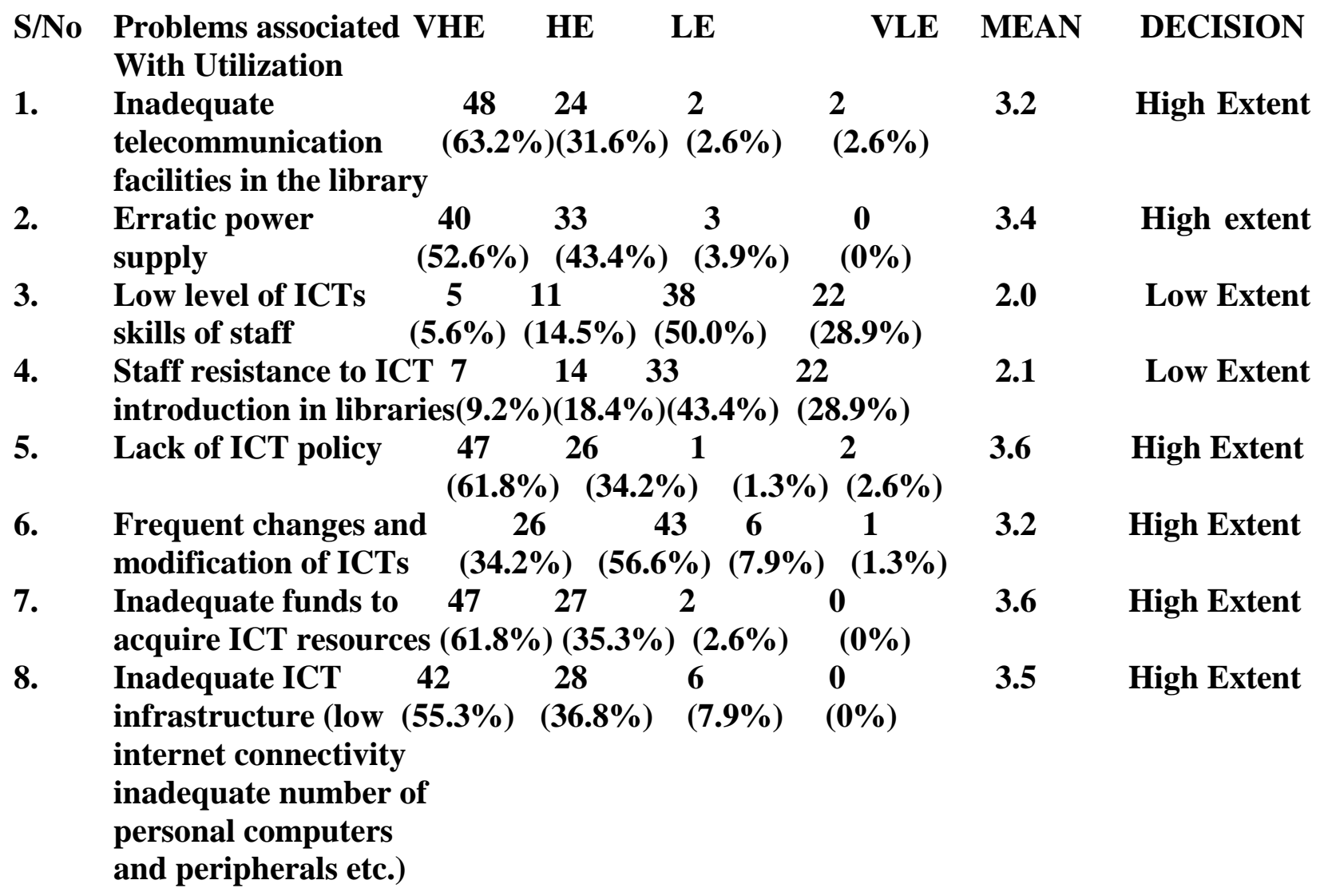

Problems associated with the utilization of ICT in service delivery in research institute libraries of the North Central Nigeria revealed that inadequate telecommunication facilities in the library 3.2, erractic power supply 3.4, lack of ICT policy 3.6, frequent changes and modifications of ICTs 3.2, inadequate fund to acquire ICT resources 3.6 and inadequate ICT infrastructure such 
Mommoh, R. S, Emmanuel, V.: Library Staff Utilization of Information and Communication Technology ICT for Service Delivery in Special Libraries in North Central, Nigeria

as low internet connectivity, inadequate number of computers and peripherals were accessed to be major problems hindering the effective use of ICT in service delivery in the special libraries. Other minimal problems includes low ICT skills of staff 2.0 and staff resistance to ICT 2.1. For effective and efficient utilization of ICT in service

\section{Discussion of Finding}

Special libraries investigated have some requisite ICT facilities available for utilization in service delivery. While some ICT facilities were found to be high, some were low. If the available ICT in special libraries are well utilized for service delivery by library staff, this could translate into better service delivery to users. This findings agree with Faboyinde (2006), Mommoh (2006), Igben and Akebo (2007), and Islam (2007) who in their research study respectively shows the different ICT facilities that were available in special libraries in Nigeria and Bangladesh. On the extent of library staff utilization of ICT for service delivery in the special libraries within the zone, the extent of ICT utilization was determined by assessing the usage of such ICT by the staff of the special libraries for different library services. From the expressed opinions of the staff, it was found that the level of ICT utilization in the service delivery in special libraries of the North Central Nigeria, these problems must be tackled. From the analysis of the problem, the major problems are the responsibility of the management of the respective organisation where the special libraries are based.

delivery of the special libraries was minimal. Apart from the use of ICT for service delivery such as circulation, serials control and accessing online resources that was high, the utilization of ICT for other services were low, this can have negative effect on service delivery in special libraries and the special libraries may not be able to satisfy their users need as expected. The findings of the study here is consistent with the study of Mommoh (2006) who surveyed twenty three special libraries in the Federal Capital Territory Abuja, and found that out of twenty three (100\%) special libraries, only nine (39\%) had computers for same library services. The finding revealed several problems associated with the use of ICT for service delivery in special libraries of the North Central Nigeria. From the opinion of the majority of the staff, problems such as inadequate telecommunication facilities, erratic power 
Mommoh, R. S, Emmanuel, V.: Library Staff Utilization of Information and Communication Technology ICT for Service Delivery in Special Libraries in North Central, Nigeria

supply, lack of ICT policy, frequent changes and modification of ICT's, inadequate fund and inadequate infrastructure such as low internet, low number of computers have constituted challenges in the use of ICT for service delivery in the North Central Nigeria. These problems are great and can negatively affect effective service delivery in the special libraries in digital age. This can lead to ineffective service delivery and users dissatisfaction with the library service in the special libraries of the North Central Nigeria. This findings agree with Oketunji (2003), Fanimehin (2008) and Maxwell (2011) who respectively identified problems

\section{Conclusion and Recommendations}

Information and communication technologies are changing the work of libraries and information center's more than ever before. Special libraries in North Central Nigeria and other part of Nigeria need adequate and relevant ICT to attend to their users need through effective service delivery. Increasing number of users, greater demand for library materials, increased in the amount of materials being published, new electronic formats and sources and development of new computers coupled with digital age are reasons while special of ICT utilization in special and research libraries to include in adequate fund to handle hardware, software installation and maintenance of these facilities, librarian perception, vested interest of the head of department where the library is, lack of suitable infrastructure for the operation of ICT in special and research libraries in Nigeria, unskilled man power, erratic power supply and lack of zeal and commitment in the implementation of ICT policy in the running of the in-house chores in the special libraries on the part of government and management of these institutes and ministries.

libraries in the North Central Nigeria needs ICT to effectively deliver their services. It was revealed that ICT's available in special libraries under study were inadequate, the utilization for service delivery is minimal and a lot of problems still hindering effective utilization of ICT for service delivery. Therefore management of special libraries in the North Central Nigeria library bodies such as Nigerian Library Association, Librarian Registration Council of Nigeria, librarians in special libraries and library supporters must help to develop ICT 
Mommoh, R. S, Emmanuel, V.: Library Staff Utilization of Information and Communication Technology ICT for Service Delivery in Special Libraries in North Central, Nigeria

facilities and ensure their utilization for effective service delivery. ICT utilization for service delivery in special libraries is indispensable for service delivery to users and in fact to the progress of librarianship. In the light of the above, special libraries budget in North Central Nigeria should be increased to accommodate and initiate the implementation of ICT tools. The management of special libraries can play a vital role by allocating sufficient funds for procurement and maintaining ICT facilities in their libraries. Parent organization of special libraries in North Central Nigeria, should provide adequate and relevant ICT infrastructure for the application of the tools. Government should have a clear cut policy on the use of ICT for service delivery in special libraries, as this will spur or encourage the library staff to make it a point of deity to use ICT for service delivery and this will lead to high use of ICT, which will in turn enhance effective service delivery that will satisfy their users and also make the special libraries in the zone to remain relevant in digital age.

Solton International Hotel and Resort Akure, 20-25 June, 10-18

Cholin, C. (2001). Information management for an intelligent organization: the Art of Environment scanning. Med ford, NJ: Learned information. 16-18.

Daniel, J.O. and Mathews, O.G. (2000). Strategies and new tools for information delivery in the research and academic libraries: Agenda for the new millennium. NLA Lagos.

Daniel, J.O. Oketunji, I. Okoji, V.O \& Abdulsalam .R. (2003) Forty years of 
Mommoh, R. S, Emmanuel, V.: Library Staff Utilization of Information and Communication Technology ICT for Service Delivery in Special Libraries in North Central, Nigeria

Information and Communication Technology (ICT). In forty years of library services in Nigeria. Lagos: Ikofa commercial press limited.

Faboyinde, E.O. (2006). The state of information communication Technology (ICT) in Selected Libraries in Lagos and Ibadan metropolis. Paper presented at the $44^{\text {th }}$ Annual conference and center for women developmentAbuja $18^{\text {th }}-23^{\text {rd }}$ June6168

Fanimehrin, A.O (2008). Planinig for Digitization of Library Materials. A paper presented at the $16^{\text {th }}$ Annual Seminar/Workshop on Globalization of information: Trends and processes in Government Libraries and Information Centres. Held at Kano, from 23-29 Nov.

Igben, M. J. and Akobo, D. I. (2007). State of Information and Communication Technology (ICT) in Libraries in Rivers state, Nigeria. African Journal of Library, Archives and Information Science vol. 17 (2) 135 - 143.

Islam, M.S and Islam M.N (2007). Use of ICT in libraries; and empirical study of selected libraries in Bangladesh. Library philosophy and practice.

Maxwell, C.E.O (2011) the role of information and communication Technologies and Resource sharing in special libraries in concepts and issues in special libraries in Nigeria. Lagos, Dat and partners logistics limited. Pp.43-61

Mommoh, R. L. (2006). Application of Computer to special library services in the Federal Capital Territory,
Nigeria. Borno library, Archival and Information Science Journal. 5 (2), 47 -53 .

Oketunji I. (2002). Application of information and communication technology in Libraries and documentation centers. On Electronic services in Nigeria Libraries. A paper presented at National workshop of Nigeria libraries Association (NLA) held at university of Agriculture Abeokuta, Ogun State $24^{\text {th }}-26$ April.3 -13.

Oketunji,I. (2001). Computer Application of information to libraries :Making a difference in the knowledge age. A compendium of papers presented at the $39^{\text {th }}$ Annual conference and AGM at Sam Mbakure Hall, Imo concord hotel Owerri 17- $22^{\text {nd }}$ June. 4.

Okezie, O.I (2009), Extent of ICT use In Research by lecturers in the social sciences in University of Portarcourt The Information Technologist: 6(2)87-94

Ukangwu J.O. (2004). Popularizing ICT in our science education delivery in Nigeria. science Teachers Today. Journal of School Science 2(1): 33 35 . 